\title{
RESEARCH ON APPLYING RISK MANAGEMENT IN THE FIELD OF QUALITY IN ORDER TO IMPROVE THE PHARMACY ACTIVITY. I. APPLYING QUALITY MANAGEMENT METHODS TO HIGHLIGHT THE CAUSES THAT CAN LEAD TO RISKS OF ERRORS IN ACTIVITIES PERFORMED BY THE PHARMACIST IN PHARMACY
}

\author{
ANAMARIA BOBOIA* \\ "Iuliu Haţieganu” University of Medicine and Pharmacy Cluj-Napoca, 8 Victor Babeş Street, 400012, Cluj-Napoca, \\ Romania, Faculty of Pharmacy, Department of Pharmaceutical Management, Marketing and Legislation
}

*corresponding author: aboboia@umfcluj.ro

Manuscript received: December 2018

\begin{abstract}
The paper objectives were researching, applying and demonstrating the utility of quality management methods in optimization of pharmacy activity, applying and assessing the impact of risk management in the field of quality of community pharmacies management. In the pharmaceutical field, the quality system is very important, and the risk management is a valuable component of an efficient quality system. The risk assessment provides a scientific and practical support for decision making. By applying the methods of quality management, this research presents the risks of errors in community pharmacy activities. The implementation of quality management methods was achieved in order to optimize pharmacies activities and increase their performance. The causes which can lead to errors in the pharmacy were identified by using Ishikawa diagram, the potential risks errors were analysed and evaluated by applying risk ranking method and relations diagram, highlighting pharmacy activities during which the risk of errors may occur. The results of the present paper provide the basis for further research to develop a program to reduce errors in the community pharmacy. There have been highlighted and quantified the causes which can lead to errors in the pharmacy, by emphasizing pharmacist activities during which risks of errors may occur. The paper has practical utility and the research results can be applied by pharmacies, contributing to improve their performance.
\end{abstract}

\section{Rezumat}

Obiectivele lucrării au fost cercetarea, aplicarea şi demonstrarea utilităţii metodelor managementului calităţii în optimizarea activităţii farmaciei, aplicarea şi evaluarea impactului managementului riscului în domeniul calității asupra managementului farmaciilor comunitare. În domeniul farmaceutic, sistemul calităţii prezintă o importanţă deosebită, iar managementul riscului în domeniul calităţii este o componentă valoroasă a unui sistem eficient al calităţii. Evaluarea riscurilor în domeniul calităţii asigură un suport ştiinţific şi practic pentru luarea deciziilor. Prin aplicarea metodelor moderne ale managementului calităţii, în această cercetare sunt prezentate riscuri de erori în activităţi din farmacia comunitară. Metodele managementului calităţii pentru optimizarea activităţilor farmaciilor şi creşterea performanţelor acestora au fost aplicate. Cauzele care pot genera erori în farmacie au fost identificate utilizând diagrama Ishikawa, riscurile potenţiale de erori au fost analizate şi evaluate prin aplicarea metodei de clasificare a riscurilor şi a diagramei de relaţii, fiind reliefate activităţile în decursul cărora pot să apară riscuri de erori. Rezultatele lucrării de faţă constituie baza unei cercetări viitoare pentru elaborarea unui program de reducere a erorilor în farmacia comunitară. S-au evidenţiat şi cuantificat cauzele care pot genera erori în farmacie, reliefându-se activităţile desfăşurate de farmacist în decursul cărora pot să apară riscuri de erori. Lucrarea prezintă utilitate practică, rezultatele cercetării putând fi aplicate de farmacii şi contribuind la îmbunătăţirea performanţelor acestora.

Keywords: risk management, quality management methods, Ishikawa diagram, risk ranking method, relation diagram, community pharmacy

\section{Introduction}

In the pharmaceutical field, the quality system is of particular importance and quality risk management is a valuable component of an effective quality system. The management of contemporary organizations can no longer be conceived without the use of scientific methods that allow the effective knowledge and application of economic laws, the efficient and rational use of resources, the stimulation and utilization of the creativity of the employees and the managers, the correct assessment of the obtained results, the optimization of the decision-making process and all functions of management, integration of the technical, economic, social, political and human dimensions of organizations $[5,10]$. 
The quality concept application represents an important step that targets the insurance of organisational competitiveness, the modelling of practices in correlation with the actual tendencies, in an effective and efficient manner [25].

The International Conference on Harmonization (ICH) Q9 defined the risk as "the combination of the probability of occurrence of harm and severity of that harm". Risk management can help organisations safeguard the quality and supply of products and services to customers, respectively patients, in the case of the pharmacy field. That implies anticipating hazards and controlling risk through a process of risk awareness, reduction and review. Risk management should be an integrated part of the organisation's business and quality management system [8]. Risk assessment is defined as "a systematic process of organizing information to support a risk decision to be made within a risk management process. It consists of the identification of hazards and the analysis and evaluation of risks associated with exposure to those hazards" [11, 26]. Risk analysis is an important dimension of enterprise management $[19,27]$.

The risk management process includes the risk assessment with the three stages: risk identification, risk analysis and risk evaluation, followed by risk control (risk reduction/risk acceptance) and risk review [8].

The study was conducted in two phases. The present paper contains the results concerning risk identification, risk analysis and risk evaluation of potential risks of errors in pharmacy activities and the following paper will approach risk control and risk review stages, bringing forward proposals to mitigate risks of errors in pharmacy activities.

The objectives of the present research were researching, applying and demonstrating the usefulness of quality management methods in optimizing the pharmacy activity, the evaluation of the causes that may lead to errors in the activities carried out in the community pharmacy.

In this research, risk identification was carried out by applying Ishikawa diagram and brainstorming technique, risk analysis and risk evaluation by using risk ranking method and relation diagram.

This research is a scientific approach on applying the modern methods of quality management in the community pharmacy field and can be useful to specialists in the pharmaceutical sector, pharmaceutical management, practitioners pharmacists in community pharmacy and in particular to the managers of pharmacies, the chief pharmacists.

\section{Materials and Methods}

The risk management in the field of quality provides a scientific and practical support for decision-making. It provides documented and reproducible methods for achieving the stages of risk management process in the field of quality, based on current knowledge of the probability, severity and sometimes the detectability of risk. Traditionally, the risks in the field of quality were evaluated and managed in a variety of informal ways (e.g. internal procedures) based, for example, on the compilation of observations, trends and other information [18, 24].

The risk can be assessed and managed using risk management tools and/ or internal procedures (e.g. standard operating procedures). Quality risk management methods and assistive statistical tools can be used in combination (e.g. probabilistic risk assessment). The combined use provides the flexibility that can facilitate the application of the risk management principles in the field of quality [2, 16, 17, 20, 24].

In the community pharmacy activities, various errors may occur. By applying modern methods of quality management, this research presents the risks of errors that can occur in the activities of community pharmacy and a further research will bring forward proposals to reduce the risk of errors in the community pharmacy. The modern methods of quality management applied in this research are: Ishikawa diagram, relation diagram and risk ranking method.

Ishikawa diagram (also called "fishbone" diagram or "cause and effect" diagram) is an important method used in quality management. The fishbone diagram is a quality tool helping to a cause and effect analysis for a problem to be solved. Ishikawa diagram identifies many possible causes for an effect or problem. It can be used to structure a brainstorming session. It sorts ideas into useful categories. It is a very helpful tool as it gives a pictorial representation of what is the cause of a problem [13, 14]. Fishbone diagrams are primarily used to identify causes associated with an event but are easily adopted to identify hazards/ risks associated with an event $[1,8]$. Ishikawa diagram was applied in this research for illustrating causes that can generate errors in dispensing, preparing, ordering, reception and storage of medicines in pharmacy.

In order to set up the activities carried out by the pharmacist and to assess the causes that may lead to the risks of errors in the community pharmacy, the brainstorming was used as a technique for stimulating the creativity in quality management. Risk management activities in quality field are carried out within multidisciplinary teams. The technique was applied with health professionals, academics, representatives of the College of Pharmacists, experienced pharmacists in the community pharmacies from Romania. From the creative group of techniques, brainstorming is the most used to solve problems [10, 21, 23]. In order to achieve the goal of the research, this technique was used in combination with other methods.

Risk ranking is a method used to compare risks and involves evaluation of multiple factors for each identified risk, e.g. weighting factors and risk scores. 
This in its simplest form leads to a two-dimensional diagram of probability of occurrence measured against the severity of the consequences if it did occur. This technique is widely used in health and safety risk management $[8,11]$.

Risk assessment basically involves the calculation of the magnitude of potential consequences (levels of impacts, severity) and the likelihood (levels of probability) of these consequences to occur. Both severity and likelihood were rated on a scale of 1 to 3 , giving a priority $[1,7,9,15]$, as follows: the likelihood (L) was ranked as 3 for likely, 2 for unlikely and 1 for highly unlikely; the severity (S) was classified as 3 for extremely harmful, 2 for harmful and 1 for slightly harmful. For each identified risk, the probability and severity are multiplied to give a risk score, with 1 as the lowest and 9 as the highest score. Once scored, the risks can be ranked, and a risk score assigned for each identified event. The weightings for severity and frequency can be modified to give a different spread of risk depending on the application and focus required [8]. Using the formula: Risk $(\mathrm{R})=$ Severity (S) x Likelihood (L), the risk score was calculated for risks that can occur in activities performed by pharmacists in pharmacy.

The relation diagram method establishes the fundamental points to be addressed and describes the logical links that connect several factors, the arrows indicating the relations "cause $\rightarrow$ consequence" [22]. The stages are the following: defining the problem, as in the case of this research: "Causes that may lead to risks of errors in the activities carried out in the community pharmacy"; exposing the possible causes of the problem; identifying cause-effect relations, indicated by an arrow pointing to the effect; resuming the diagram, performing the necessary corrections and identifying the key factors $[6,12]$.

Relation diagram was used in this research in order to highlight the causes of highest risks of errors in the community pharmacy activities, with the highest risk scores calculated.

\section{Results and Discussion}

Applying the Ishikawa diagram and the risk ranking method for setting up the errors risks in pharmacy activities

Risk assessment (risk identification, risk analysis and risk evaluation) was carried out for the following activities accomplished by the pharmacist: preparing pharmaceutical preparations; dispense of medicines and other health products, including dispense of the reimbursed medicines and of the preparations; ordering medicines and other products; reception of medicines and other products; storage, preservation and arranging the products in the pharmacy dispensary and deposit. Because of the multitude of causes that can lead to errors, the potential errors risks were identified by applying Ishikawa diagram (Figure 1) for the following activities: preparation of medicines in pharmacy (A), dispensing products in pharmacy (B), ordering products (C), reception (D), storage, preservation and arranging of products in pharmacy $(\mathrm{E})$.

In Table I are presented the risk scores calculated for the errors that can occur in the main activities performed by pharmacists in pharmacy (preparation, dispensing, ordering, reception, storage).

Table I

Risk assessment in activities performed by pharmacists in pharmacy

\begin{tabular}{|c|c|c|c|}
\hline \multirow{2}{*}{$\begin{array}{c}\text { Activities } \\
\text { Potential risks/ hazards } \\
\end{array}$} & \multicolumn{2}{|c|}{ Risk analysis } & \multirow{2}{*}{$\begin{array}{l}\text { Risk evaluation } \\
\text { Risk score (SxL) } \\
\end{array}$} \\
\hline & Severity (S) & Likelihood (L) & \\
\hline \multicolumn{4}{|l|}{ PREPARATION ERRORS } \\
\hline \multicolumn{4}{|l|}{ Personnel } \\
\hline Insufficient training/ documentation of personnel & 3 & 2 & 6 \\
\hline Fatigue/ overwork/multitasking & 2 & 2 & 4 \\
\hline Insufficient focus on compounding activity & 3 & 1 & 3 \\
\hline \multicolumn{4}{|l|}{ Methods } \\
\hline Inadequate preparation method/ technique & 3 & 3 & 9 \\
\hline \multicolumn{4}{|l|}{ Materials } \\
\hline Wrong pharmaceutical substances used & 3 & 3 & 9 \\
\hline $\begin{array}{l}\text { Inappropriate quality of substances (expired, inadequately stored, } \\
\text { improperly packed etc.) }\end{array}$ & 3 & 3 & 9 \\
\hline Erroneous concentrations of substances & 3 & 2 & 6 \\
\hline \multicolumn{4}{|l|}{ Measurements, calculations } \\
\hline Incorrect weighing & 3 & 2 & 6 \\
\hline Wrong calculations (incorrect doses, isotonicity agents etc.) & 3 & 2 & 6 \\
\hline \multicolumn{4}{|l|}{ Environment } \\
\hline $\begin{array}{l}\text { Lack of cleanliness of the workplace in the pharmacy's } \\
\text { compounding room }\end{array}$ & 3 & 1 & 3 \\
\hline Occasional excessive noise in the pharmacy & 1 & 1 & 1 \\
\hline Interruptions during preparation & 2 & 1 & 2 \\
\hline
\end{tabular}


FARMACIA, 2019, Vol. 67, 6

\begin{tabular}{|c|c|c|c|}
\hline \multirow{2}{*}{$\begin{array}{c}\text { Activities } \\
\text { Potential risks/ hazards }\end{array}$} & \multicolumn{2}{|c|}{ Risk analysis } & \multirow{2}{*}{$\begin{array}{c}\text { Risk evaluation } \\
\text { Risk score (SxL) }\end{array}$} \\
\hline & Severity (S) & Likelihood (L) & \\
\hline \multicolumn{4}{|l|}{ Equipment } \\
\hline Defective measuring instruments (balances) & 3 & 2 & 6 \\
\hline Failure to check periodically the accuracy of balances & 3 & 1 & 3 \\
\hline Inaccuracy of measuring instruments & 3 & 2 & 6 \\
\hline \multicolumn{4}{|l|}{ DISPENSING PRODUCTS ERRORS } \\
\hline \multicolumn{4}{|l|}{ Dispensing erroneous products } \\
\hline Dispensing wrong quantities & 3 & 2 & 6 \\
\hline Dispensing erroneous doses & 3 & 2 & 6 \\
\hline Dispensing wrong concentrations & 2 & 2 & 4 \\
\hline Dispensing wrong pharmaceutical forms & 3 & 1 & 3 \\
\hline Dispensing expired medicines & 3 & 2 & 6 \\
\hline \multicolumn{4}{|l|}{ Dispensing wrong resembling products } \\
\hline Dispensing wrong products with similar trade name & 3 & 2 & 6 \\
\hline Dispensing wrong products with similar packaging & 3 & 2 & 6 \\
\hline Wrong replacement of medicines & 3 & 3 & 9 \\
\hline \multicolumn{4}{|l|}{ Erroneous counselling } \\
\hline Incorrect information and inaccurate advice on the posology & 3 & 2 & 6 \\
\hline $\begin{array}{l}\text { Inaccurate advice on the correct medicines storage mode at } \\
\text { patient's residence }\end{array}$ & 3 & 2 & 6 \\
\hline \multicolumn{4}{|l|}{ Erroneous packaging } \\
\hline Dispensing products with deteriorated packaging & 2 & 2 & 4 \\
\hline Dispensing wrong medicines erroneously packed & 3 & 2 & 6 \\
\hline \multicolumn{4}{|l|}{ Incorrect registering } \\
\hline Incorrect registering in the pharmaceutical management software & 2 & 2 & 4 \\
\hline \multicolumn{4}{|l|}{ ORDERING PRODUCTS ERRORS } \\
\hline \multicolumn{4}{|l|}{$\begin{array}{c}\text { Causes with higher impact on the pharmacy supply and } \\
\text { profitability }\end{array}$} \\
\hline $\begin{array}{l}\text { Failure to study carefully the offers of the deposits for selecting the } \\
\text { most advantageous ones }\end{array}$ & 3 & 2 & 6 \\
\hline Not to order necessary products & 3 & 2 & 6 \\
\hline Failure to perform stock management & 3 & 2 & 6 \\
\hline \multicolumn{4}{|l|}{ Wrong products orders } \\
\hline $\begin{array}{c}\text { Erroneous orders (wrong products, from another manufacturer, } \\
\text { another supplier etc.) }\end{array}$ & 3 & 2 & 6 \\
\hline $\begin{array}{l}\text { Ordering inappropriate quantities of products (too large or too } \\
\text { small) in relation to the needs of the pharmacy }\end{array}$ & 3 & 2 & 6 \\
\hline \multicolumn{4}{|l|}{ Personnel } \\
\hline Ignorance of existing stock by the pharmacist & 3 & 1 & 3 \\
\hline $\begin{array}{l}\text { Inattention to the packaging, the differences in concentrations of } \\
\text { products etc. }\end{array}$ & 3 & 1 & 3 \\
\hline \multicolumn{4}{|l|}{ Suppliers } \\
\hline Non-operation of the order by the supplier & 3 & 1 & 3 \\
\hline $\begin{array}{c}\text { Lack of promptness and the quality of the services provided by the } \\
\text { deposit }\end{array}$ & 2 & 2 & 4 \\
\hline \multicolumn{4}{|l|}{ RECEPTION ERRORS } \\
\hline \multicolumn{4}{|l|}{ Quantitative reception } \\
\hline Inaccurate counting of products received & 2 & 2 & 4 \\
\hline Wrong weighing of the pharmaceutical substances received & 3 & 1 & 3 \\
\hline $\begin{array}{l}\text { Not identifying the discrepancies between the data from the } \\
\text { invoices and products received }\end{array}$ & 3 & 2 & 6 \\
\hline \multicolumn{4}{|l|}{ Qualitative reception } \\
\hline $\begin{array}{l}\text { Failure to check the apparent defects (ex. broken packaging, } \\
\text { damaged blisters etc.) for pharmaceutical specialties and other } \\
\text { health products }\end{array}$ & 3 & 1 & 3 \\
\hline Not verifying the period of validity of the products & 3 & 2 & 6 \\
\hline $\begin{array}{l}\text { Omission of execution of identification reactions (according } \\
\text { Pharmacopoeia) for pharmaceutical substances received }\end{array}$ & 3 & 3 & 9 \\
\hline \multicolumn{4}{|l|}{ Reception in terms of value } \\
\hline Omission of verifying of prices and calculations on the invoices & 3 & 1 & 3 \\
\hline Wrong calculation and display of the retail prices & 2 & 2 & 4 \\
\hline
\end{tabular}


FARMACIA, 2019, Vol. 67, 6

\begin{tabular}{|c|c|c|c|}
\hline \multirow{2}{*}{$\begin{array}{c}\text { Activities } \\
\text { Potential risks/ hazards }\end{array}$} & \multicolumn{2}{|c|}{ Risk analysis } & \multirow{2}{*}{$\begin{array}{c}\text { Risk evaluation } \\
\text { Risk score (SxL) }\end{array}$} \\
\hline & Severity (S) & Likelihood (L) & \\
\hline \multicolumn{4}{|l|}{ Personnel } \\
\hline Inattention/ fatigue of the personnel & 3 & 1 & 3 \\
\hline Not knowing all pharmaceutical forms & 3 & 1 & 3 \\
\hline $\begin{array}{l}\text { Person receiving the products is involved in several activities at the } \\
\text { same time }\end{array}$ & 2 & 2 & 4 \\
\hline \multicolumn{4}{|l|}{ Documents } \\
\hline $\begin{array}{l}\text { Non-accomplishment of the reception note for each invoice } \\
\text { received in the pharmacy }\end{array}$ & 3 & 1 & 3 \\
\hline \multicolumn{4}{|l|}{$\begin{array}{c}\text { STORAGE ERRORS } \\
\end{array}$} \\
\hline \multicolumn{4}{|l|}{ Personnel } \\
\hline $\begin{array}{l}\text { Failure to comply with the appropriate conditions of storage and } \\
\text { preservation of products }\end{array}$ & 3 & 2 & 6 \\
\hline $\begin{array}{l}\text { Failure to comply with the mode of storage and arrangement of } \\
\text { products, used at the unity level }\end{array}$ & 2 & 2 & 4 \\
\hline Inobservance of special storage conditions & 3 & 2 & 6 \\
\hline $\begin{array}{l}\text { Failure to comply with the appropriate arrangement criteria for } \\
\text { medicines and other health products in pharmacy }\end{array}$ & 2 & 2 & 4 \\
\hline \multicolumn{4}{|l|}{ Measurements } \\
\hline Inaccurate measurements of parameters that influence preservation & 3 & 1 & 3 \\
\hline \multicolumn{4}{|l|}{$\begin{array}{ll}\text { Environment } \\
\end{array}$} \\
\hline $\begin{array}{l}\text { Infringement of the appropriate storage conditions taking into } \\
\text { account the environmental factors that can affect the preservation } \\
\text { of drugs (temperature, humidity, light, atmospheric air etc.) }\end{array}$ & 3 & 3 & 9 \\
\hline \multicolumn{4}{|l|}{ Equipment } \\
\hline $\begin{array}{c}\text { Failure of equipment for ensuring the necessary preservation } \\
\text { conditions (e.g. pharmacy display refrigerators etc.) }\end{array}$ & 3 & 1 & 3 \\
\hline $\begin{array}{l}\text { Failure of appropriate instruments to measure factors that may } \\
\text { affect storage and preservation (e.g. thermometers, hygrometers etc.) }\end{array}$ & 3 & 1 & 3 \\
\hline
\end{tabular}

There have been identified a total number of 57 potential errors risks from which 15 for preparing activity (grouped in 6 categories: personnel, methods, materials, measurements, environment, equipment), 13 potential errors risks for dispensing activity (grouped in 5 categories: dispensing erroneous products, dispensing wrong resembling products, erroneous counselling, erroneous packaging, incorrect registering), 12 causes of risks errors for reception activity (grouped in 5 categories: reception in terms of quantity, quality, value, documents, personnel), 9 causes of errors for products ordering activity in pharmacy (grouped in 4 categories: causes with higher impact on the pharmacy supply and profitability, wrong products orders, personnel, suppliers), and 8 causes of errors for storage and preservation activity (grouped in 4 categories: personnel, measurements, environment, equipment).

The risk ranking technique works by assigning values to the probability of occurrence and the severity of the outcome to give a two-dimensional view. For example, in its simplest form, a risk that is present but highly unlikely to occur has a low probability with a score of 1 assigned. Account should also be taken of what the consequences would be if the risk become reality i.e. severity. If the consequences are severe in effect, then this would be assigned a severity of high with a score of 3 . In this example, it translates as a risk score 1 x $3=3$ (medium).

Applying the risk ranking, the scores obtained, which can be observed in the right columns of Tables I and II, indicate the risk rating: score 1 (insignificant risk): no action is required; score 2 (low risk): largely acceptable, subject to reviews periodically; score 3 or 4 (medium risk): actions should be made to mitigate the risk, the costs of prevention should be carefully measured; score 6 (high risk): work activities should not be started until the risk has been mitigated; significant resources may have to be allocated to mitigate the risk; where the risk involves work in progress, urgent action should be taken; score 9 (extreme risk): work should not be continued until the risk has been mitigated. 

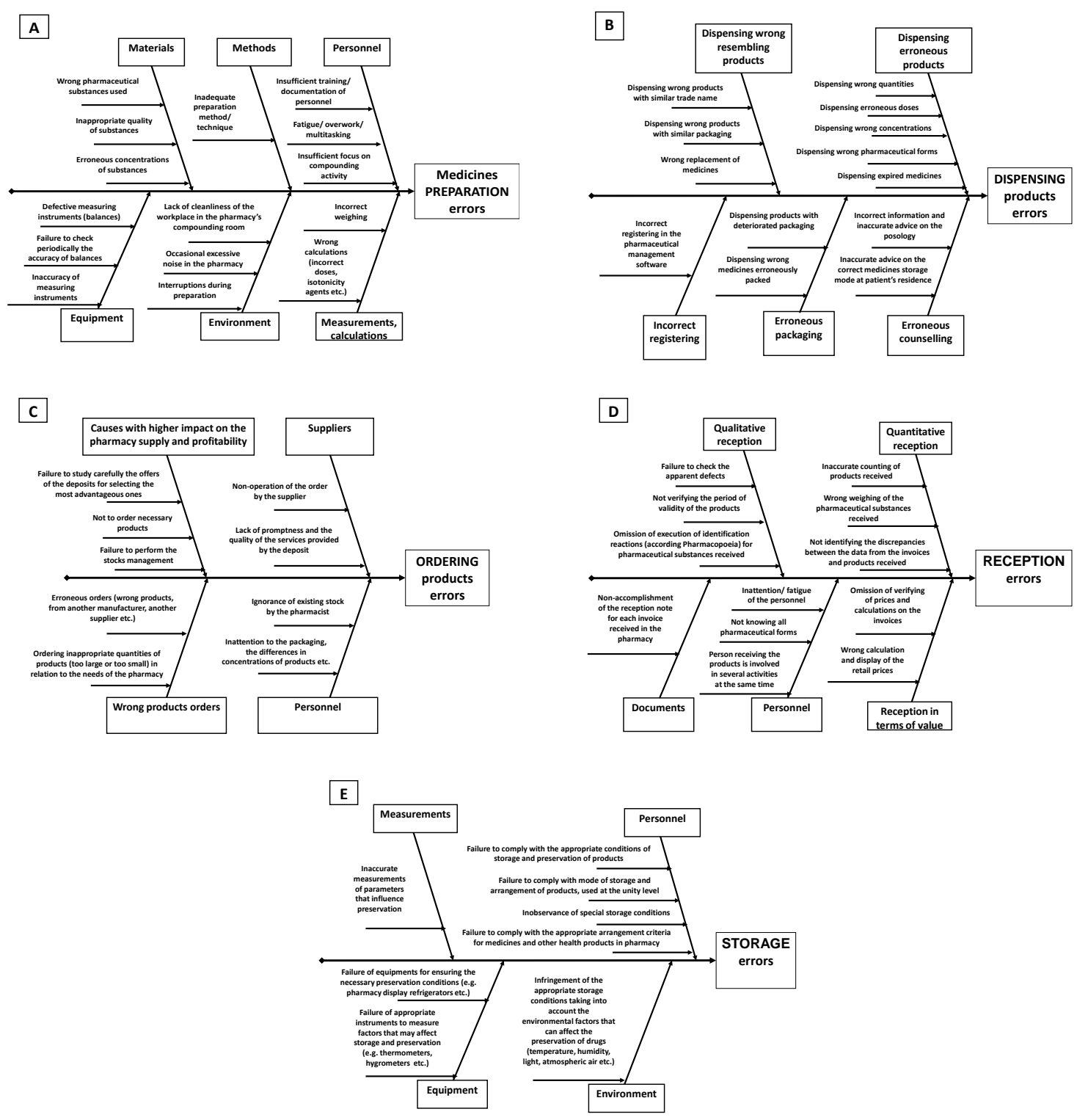

Figure 1.

Ishikawa diagram illustrating causes that can generate errors in pharmacy activities: preparation (A), dispensing (B), ordering (C), reception (D) and storage (E)

Table II

The classification of the potential errors' risks based on the risk score obtained

\begin{tabular}{|c|c|}
\hline $\begin{array}{c}\text { Activities } \\
\text { Potential risks }\end{array}$ & Risk evaluation \\
\cline { 2 - 2 } PREPARATION ERRORS & Risk score \\
\hline Materials & \\
\hline Wrong pharmaceutical substances used & 9 (Extreme) \\
\hline Erroneous concentrations of substances & 9 (Extreme) \\
\hline Methods & 6 (High) \\
\hline Inadequate preparation method/ technique & 9 (Extreme) \\
\hline Measurements, calculations & \\
\hline Incorrect weighing & 6 (High) \\
\hline Wrong calculations (incorrect doses, isotonicity agents etc.) & 6 (High) \\
\hline Eefective measuring instruments (balances) & \\
\hline Inaccuracy of measuring instruments & 6 (High) \\
\hline
\end{tabular}


FARMACIA, 2019, Vol. 67, 6

\begin{tabular}{|c|c|}
\hline $\begin{array}{c}\text { Activities } \\
\end{array}$ & Risk evaluation \\
\hline Failure to check periodically the accuracy of balances & 3 (Medium) \\
\hline \multicolumn{2}{|l|}{ Personnel } \\
\hline Insufficient training/ documentation of personnel & 6 (High) \\
\hline Fatigue/ overwork/ multitasking & 4 (Medium) \\
\hline Insufficient focus on compounding activity & 3 (Medium) \\
\hline \multicolumn{2}{|l|}{ Environment } \\
\hline Lack of cleanliness of the workplace in the pharmacy's compounding room & 3 (Medium) \\
\hline Interruptions during preparation & 2 (Low) \\
\hline Occasional excessive noise in the pharmacy & 1 (Insignificant) \\
\hline \multicolumn{2}{|l|}{ DISPENSING PRODUCTS ERRORS } \\
\hline \multicolumn{2}{|l|}{ Dispensing wrong resembling products } \\
\hline Wrong replacement of medicines & 9 (Extreme) \\
\hline Dispensing wrong products with similar trade name & 6 (High) \\
\hline Dispensing wrong products with similar packaging & 6 (High) \\
\hline \multicolumn{2}{|l|}{ Dispensing erroneous products } \\
\hline Dispensing expired medicines & 6 (High) \\
\hline Dispensing erroneous doses & 6 (High) \\
\hline Dispensing wrong quantities & 6 (High) \\
\hline Dispensing wrong concentrations & 4 (Medium) \\
\hline Dispensing wrong pharmaceutical forms & 3 (Medium) \\
\hline \multicolumn{2}{|l|}{ Erroneous counselling } \\
\hline Incorrect information and inaccurate advice on the posology & 6 (High) \\
\hline Inaccurate advice on the correct medicines storage mode at patient's residence & 6 (High) \\
\hline \multicolumn{2}{|l|}{ Incorrect registering } \\
\hline Incorrect registering in the pharmaceutical management software & 4 (Medium) \\
\hline \multicolumn{2}{|l|}{ Erroneous packaging } \\
\hline Dispensing wrong medicines erroneously packed & 6 (High) \\
\hline Dispensing products with deteriorated packaging & 4 (Medium) \\
\hline \multicolumn{2}{|l|}{ ORDERING PRODUCTS ERRORS } \\
\hline \multicolumn{2}{|l|}{ Causes with higher impact on the pharmacy supply and profitability } \\
\hline Failure to study carefully the offers of the deposits for selecting the most advantageous ones & 6 (High) \\
\hline Not to order necessary products & 6 (High) \\
\hline Failure to perform stock management & 6 (High) \\
\hline \multicolumn{2}{|l|}{$\begin{array}{l}\text { Wrong products orders } \\
\end{array}$} \\
\hline Erroneous orders (wrong products, from another manufacturer, another supplier etc.) & 6 (High) \\
\hline $\begin{array}{l}\text { Ordering inappropriate quantities of products (too large or too small) in relation to the needs of the } \\
\text { pharmacy }\end{array}$ & 6 (High) \\
\hline \multicolumn{2}{|l|}{ Personnel } \\
\hline Ignorance of existing stock by the pharmacist & 3 (Medium) \\
\hline Inattention to the packaging, the differences in concentrations of products etc. & 3 (Medium) \\
\hline \multicolumn{2}{|l|}{ Suppliers } \\
\hline Lack of promptness and the quality of the services provided by the deposit & 4 (Medium) \\
\hline Non-operation of the order by the supplier & 3 (Medium) \\
\hline \multicolumn{2}{|l|}{ RECEPTION ERRORS } \\
\hline \multicolumn{2}{|l|}{$\begin{array}{l}\text { Qualitative reception } \\
\end{array}$} \\
\hline $\begin{array}{l}\text { Omission of execution of identification reactions (according Pharmacopoeia) for pharmaceutical } \\
\text { substances received }\end{array}$ & 9 (Extreme) \\
\hline Not verifying the period of validity of the products & 6 (High) \\
\hline $\begin{array}{l}\text { Failure to check the apparent defects (ex. broken packaging, damaged blisters etc.) for } \\
\text { pharmaceutical specialties and other health products }\end{array}$ & 3 (Medium) \\
\hline \multicolumn{2}{|l|}{$\begin{array}{l}\text { Quantitative reception } \\
\end{array}$} \\
\hline Not identifying the discrepancies between the data from the invoices and products received & 6 (High) \\
\hline Inaccurate counting of products received & 4 (Medium) \\
\hline Wrong weighing of the pharmaceutical substances received & 3 (Medium) \\
\hline \multicolumn{2}{|l|}{ Reception in terms of value } \\
\hline Wrong calculation and display of the retail prices & 4 (Medium) \\
\hline Omission of verifying of prices and calculations on the invoices & 3 (Medium) \\
\hline \multicolumn{2}{|l|}{ Personnel } \\
\hline Person receiving the products is involved in several activities at the same time & 4 (Medium) \\
\hline
\end{tabular}


FARMACIA, 2019, Vol. 67, 6

\begin{tabular}{|c|c|}
\hline Activities & Risk evaluation \\
\hline Inattention/ fatigue of the personnel & 3 (Medium) \\
\hline Not knowing all pharmaceutical forms & 3 (Medium) \\
\hline Documents & 3 (Medium) \\
\hline STORAGE ERRORS & \\
\hline Environment & 9 (Extreme) \\
\hline $\begin{array}{c}\text { Infringement of the appropriate storage conditions taking into account the environmental factors } \\
\text { that can affect the preservation of drugs (temperature, humidity, light, atmospheric air etc.) }\end{array}$ & \\
\hline Personnel & 6 (High) \\
\hline Failure to comply with the appropriate conditions of storage and preservation of products & 6 (High) \\
\hline Inobservance of special storage conditions & 4 (Medium) \\
\hline Failure to comply with mode of storage and arrangement of products, used at the unity level & 4 (Medium) \\
\hline $\begin{array}{c}\text { Failure to comply with the appropriate arrangement criteria for medicines and other health products } \\
\text { in pharmacy }\end{array}$ & \\
\hline Equipment & 3 (Medium) \\
\hline $\begin{array}{c}\text { Failure of equipments for ensuring the necessary preservation conditions (e.g. pharmacy display } \\
\text { refrigerators etc.) }\end{array}$ & 3 (Medium) \\
\hline $\begin{array}{c}\text { Failure of appropriate instruments to measure factors that may affect storage and preservation (e.g. } \\
\text { thermometers, hygrometers etc.) }\end{array}$ & 3 (Medium) \\
\hline Measurements &
\end{tabular}

The Maximum score of 9 (extreme) was obtained by a number of 6 errors risks, from which the most for preparation activity (that accumulated 3 maximum extreme scores of 9), then activities of dispensing, reception and storage (each of them with 1 extreme score). High scores of 6 have recorded a number of 23 risk errors (from which 8 high scores accumulated dispensing activity, 6 preparation, 5 ordering, 2 reception and storage activities). Medium scores (3 and 4) recorded 23 error risks and low scores obtained 2 error risks.

Applying the relation diagram to assess the causes that may lead to the highest risks of errors in activities carried out in the community pharmacy

The potential error risks, which have obtained the highest risk scores in the previous evaluation stage of risk assessment, have been pointed out using the relation diagram (Figure 2 ).

In the activity of preparation of medicines in the pharmacy, the causes that can generate the highest risks of errors are: inappropriate quality of substances (expired, inadequately stored, improperly packed etc.), wrong pharmaceutical substances used (e.g. use of other substances than those prescribed), inadequate preparation method/technique (score 9, extreme risk); insufficient training/documentation of personnel, wrong calculations (incorrect doses, isotonicity agents etc.), incorrect weighing of substances, use of erroneous concentrations of substances, inaccuracy of measuring instruments (score 6, high risk).

In dispensing products from the pharmacy, the facts that can cause the highest risks of errors can be: wrong replacement of medicines (score 9, extreme risk); erroneous counselling (incorrect information and inaccurate advice on the posology, inaccurate advice on the correct medicines storage mode at patient's residence), dispensing erroneous products, wrong quantities and expired medicines (score 6, high risk). In the activity of ordering products, causes that can determine risks of errors are: erroneous orders (wrong products, from another manufacturer, another supplier etc.), not to order products that are missing from the pharmacy, not performing the stock management, ordering inappropriate quantities of products in relation to the needs of the pharmacy (e.g. large quantities of products that may expire), failure to study carefully the offers of the deposits for selecting the most advantageous ones (score 6, high risk). The high scores of errors risk in ordering products in pharmacy can be explained by the fact this activity represents an important step for a good management of pharmacy and errors in this activity can affect the pharmacy profitability [4]. Pharmacy supply is an extremely important activity. A good supply of pharmacy represents an important prerequisite for the growth of sales [3]. There must be current stocks (for daily sales) and safety stocks in the pharmacy. There must be a balance between stocks and consumption. The risks of owning an increased stock of products generate two types of costs: costs of the procurement activity and storage costs. In the activity of reception of pharmaceutical products, the causes that can generate risks of errors include the followings: omission of execution of identification reactions provided by Pharmacopoeia, edition in force, for pharmaceutical substances (score 9, extreme risk); failure to identify the discrepancies between the data from the invoices and products received in pharmacy, not verifying the shelf life of the products (score 6 , high risk). 


\section{DIAGRAM OF RELATIONS}

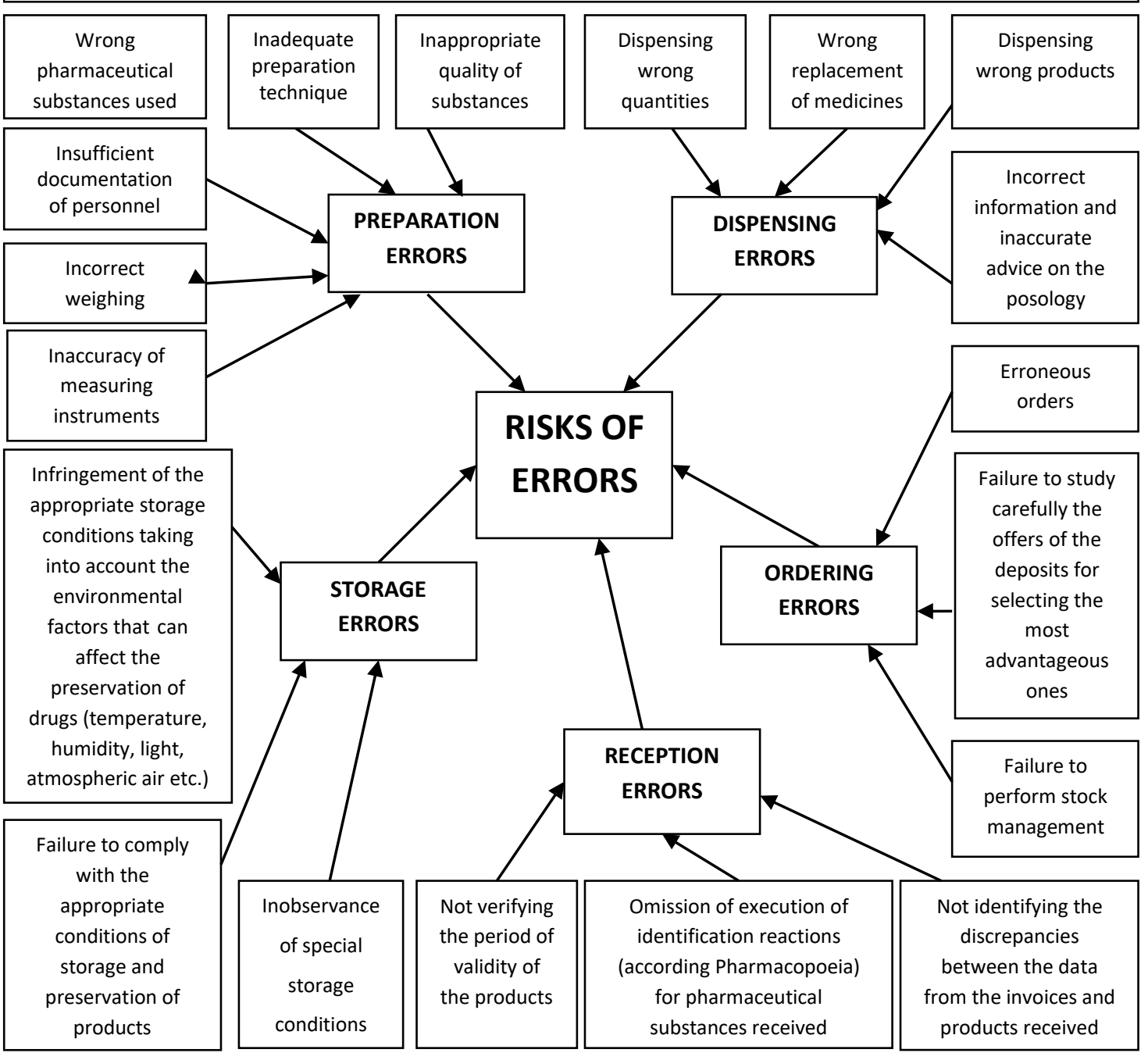

Figure 2.

Diagram of relations with the theme "Causes that determine apparition of highest risks of errors in the community pharmacy"

Causes that can determine risks of errors to storing products in the pharmacy include: failure to appropriate storage taking into account the environmental factors that can affect the preservation of drugs (score 9, extreme risk); inobservance of special storage conditions, failure to comply with the appropriate conditions of storage and preservation of products (score 6, high risk).

Pharmacy activity must be centred on the patient well, which must receive quality pharmaceutical services and products. First of all, patient safety and treatment efficiency must be targeted. Patients must obtain from pharmacies adequate products and services of the appropriate quality.

The causes that can generate considerable risks of errors in activities performed in pharmacies must be taken into account, in order to take measures to mitigate them. Strategies and proposals to reduce errors in pharmacy activities will be presented in future studies.

\section{Conclusions}

In the pharmaceutical field, the quality system is of a special importance and risk management in the quality field provides scientific and practical support for decision making.

Applying Ishikawa diagram, risk ranking method and relations diagram, the causes of the risks of errors in the activities carried out in pharmacy by pharmacists were identified and highlighted, the results of the present paper being the basis for the future research with proposals to reduce the risk of errors in the community pharmacy. Ishikawa diagram depicted the potential errors risks in pharmacy activities, the relation diagram presents the risks of errors in pharmacy activities, which obtained the highest risk scores in risk analysis and evaluation stages. 
In this research, quality management methods were used to optimize activities of pharmacies and increase their performance. The paper presents practical utility, the results of the research can be applied by the pharmacies, contributing to the improvement of their performances and to the modernization of pharmaceutical management.

\section{References}

1. Achim M, Tefas LR, Iovanov R, Vonica-Gligor AL, Barbu-Tudoran L, Tomuţă I, Preparation and in vitro evaluation of felodipine-loaded poli $(\varepsilon-$ caprolactone) microspheres: quality by design approach. Farmacia, 2019; 67(4): 670-683.

2. Aven T, Risk assessment and risk management: review of recent advances on their foundation, Eur J Oper Res., 2016; 253(1): 1-13.

3. Boboia A, Feher LA, Cuc S, Moldovan M, Comparative study between the sales of antiulcer drugs H2 Antagonists and Proton Pump Inhibitors. Farmacia, 2017; 65(4): 635-642.

4. Boboia A, Oros GC, Polinicencu C, Mirel S, Researches concerning the profitability of the community pharmacy within the context of world economic and financial crisis. Farmacia, 2014; 62(5): 1025-1036.

5. Boboia A, Polinicencu C, Application of the Pareto analysis regarding the research on the value of preparations in community pharmacies from ClujNapoca, Romania. Farmacia, 2012; 60(4): 578-585.

6. Boca GD, Fundamentals of quality management in business, Risoprint, Cluj-Napoca, 2013, (available in Romanian).

7. Casian T, Iurian S, Bogdan C, Rus L, Moldovan M, Tomuta I, QbD for pediatric oral lyophilisates development: risk assessment followed by screening and optimization. Drug Dev Ind Pharm., 2017; 43(12): 1932-1944.

8. Chartered Quality Institute, Pharmaceutical Quality Group, A guide to supply chain risk management for the pharmaceutical and medical device industries and their suppliers, 2010, (available at www.pqg.org).

9. Cooke B, Williams P, Construction, planning, programming and control, $3^{\text {rd }}$ edition, Blackwell Publishing, Oxford, 2009.

10. Cornescu V, Mihăilescu I, Stanciu S, Organization Management, All Beck, Bucharest, 2003, (available in Romanian).

11. European Medicines Agency, ICH guideline Q9 on quality risk management, 2015.

12. Ioniţă I, Quality management of technical-economic systems, www.biblioteca-digitala.ase.ro, (available in Romanian).
13. Ishikawa $\mathrm{K}$, Guide to quality control, Asian Productivity Organization, Tokyo, 1996.

14. Ishikawa K, Quality management: tools and practical applications, Dunod, Paris, 2007, (available in French).

15. Iurian S, Turdean L, Tomuta I, Risk assessment and experimental design in the development of a prolonged release drug delivery system with paliperidone. Drug Des Devel Ther., 2017; 11: 733-746.

16. Krishna Rama SV, Srivastana P, Risk management in pharmaceuticals, Mintage J. Pharm. Med. Sci., 2014; 3(2): 1-4.

17. Kumar N, Jha A, Quality risk management during pharmaceutical "good distribution practices" - a plausible solution, Bulletin of Faculty of Pharmacy, Cairo University, 2018; 56(1): 18-25.

18. Marinescu SA, Bejinariu CG, Giuglea C, Research Related to Breast Implant-associated Anaplastic Large Cell Lymphoma and its Influence on the Decision-Making Process Related to Reconstructive Techniques. Analysis of a series of cases and literature review. Mater Plast., 2019; 56(1): 229-234.

19. Mironiuc M, Methodology of analysis of economic risk for the multi-product enterprise, Scientific Annals of "Alexandru Ioan Cuza University", Iași, Tome LII/LIII, 2005/2006, (available in Romanian).

20. Oltean AM, Crişan O, Risk management in preventing medication errors in a community pharmacy. Farmacia, 2018; 66(4): 725-732.

21. Pânişoară G, Pânişoară IO, Human resources management: practical guide, $3^{\text {rd }}$ edition, Polirom, Iaşi, 2016, (available in Romanian).

22. Périgord M, The stages of the quality. Approaches and tools, Technical Publishing House, Bucharest, 1997, (available in Romanian).

23. Proctor T, Elements of managerial creativity, Teora, Bucharest, 2000, (available in Romanian).

24. Scientific Council of the National Agency for Medicines and Medical Devices, Decision no. 23/2015 on the adoption of the Guideline on Good Manufacturing Practice for Medicinal Products for Human Use, (available in Romanian).

25. Tăerel AE, Soroceanu V, Rais C, Stancu E, Study of quality standards application in Bucharest community pharmacies. Farmacia, 2014; 62(6): 1082-1088.

26. Teasdale A, Elder D, Nims WR (eds.), ICH quality guidelines: an implementation guide, Wiley, NJ, 2018.

27. Vintilă G, Armeanu DS, Filipescu OM, Moscalu M, Lazăr P, Analysis and evaluation of risks of entrepreneurial activity in the Romanian economic environment. Theoretical and Applied Economics, 2011; 18(5): 119-131, (available in Romanian). 